\title{
Legal Review On Auction Sales Of Mortgage Rights Object On Agricultural Land And Its Registration
}

\begin{abstract}
Hardiansah ${ }^{1}$ and Amin Purnawan ${ }^{2}$
Abstract. Agrarian Law is one of the legal materials that are directly related to the livelihood of every individual society and the order of life of Indonesian society. The citizens until now are still very dependent on the activities and efforts that mostly work as agrarian, so that the land is one of Agrarian object which is the support and hope for every individual society in order to carry out a prosperous life order. The process of selling the land is divided into two ways: general sales and special sales by auction conducted by the State Property Office and Auction. This auction is conducted in the framework of repayment of debt secured by mortgage rights. This matter is regulated in Act No. 4 Of 1996 concerning Land Mortgage Rights and Objects Related to the Land and Regulation of Minister of Finance Number 27/PMK.06/2016 concerning Guideline for Auction Implementation of Auction or public sale is a part of the occurrence the transfer of rights. According to Article 41 paragraph (1) of Government Regulation No. 24 of 1997 concerning Land Registration explains that the transfer of rights through auction can only be registered if it is proven by quotation of auction minutes made by auction officials.

Keywords: Auction Sales; Mortgage Right Objects; Land Registration.
\end{abstract}

\section{Introduction}

Agrarian Law is one of the legal materials that is directly related to the livelihood of every individual society and the order of life of Indonesian society. People until now still highly dependent on the activities and efforts of most them are agrarian, so that the land is one of Agrarian object which is the support and hope for every individual society in order to carry out a prosperous life order. ${ }^{3}$

Land is one of the main sources for the survival and livelihood of the nation in achieving the greatest prosperity of the people and spread equitably and equitably. People use the land to cultivate or for the fulfillment of real needs. Accordingly, the provision, appropriation, control, use and maintenance of the land should be regulated to ensure legal certainty in the control and utilization as well as to provide legal protection for the common people, especially the farmers. It is done along with maintaining the sustainability of their capabilities in supporting sustainable development activities. ${ }^{4}$

The process of selling the land is divided into two ways: general sales and special sales by auction conducted by KPKNL (Office of State Wealth Service and Auction). ${ }^{5}$

Here, the author only highlights the sales process in particular way, namely the transfer of rights to land through auction (public sale), where the auction is implemented in order to repay the debt guaranteed by the mortgage right. This matter is regulated in Act No. 4 Of 1996 concerning Land Mortgage Rights and Objects

\footnotetext{
${ }^{1}$ Master of Notary's Student, Sultan Agung Islamic University (UNISSULA), Semarang, email hardiansah363@gmail.com

${ }^{2}$ Lecture of Faculty of Law UNISSULA

3 Boedi Harsono , 1999, Hukum Agraria Indonesia, Sejarah Pembentukan Undang-undang Pokok Agraria, isi dan pelaksanaannya, Djambatan, revision edition, p. 317-318

${ }^{4}$ L.J. Van Apeldorn Mr, 2001, Pengantar I/mu Hukum, Pradnya Paramita, Jakarta p. 6

${ }^{5}$ Harun Al-Rashid, 1997, Sekilas Jual Beli Tanah, Ghalia Indonesia, Jakarta, p. 50
} 
Related to the Land and Regulation of Minister of Finance Number 27/PMK.06/2016 concerning Guideline for Implementation of Auction.

The mortgage right is a material security institution for land rights and land-related items for certain debt repayment, which gives priority to a particular creditor to a creditor holding the Insurance Rights to other creditors. Guarantees granted in Mortgage Rights, ie, prioritized rights to other creditors to creditors of Holders of Mortgages. ${ }^{6}$

Public auctions or sales are part of the transition. According to Article 41 paragraph (1) of Government Regulation No. 24 of 1997 concerning Land Registration explains that the transfer of rights through auction can only be registered if proven by quotation of auction minutes made by auction officials.

Whereas in Article 3 paragraph (1) of Government Regulation No. 224/1961 on the Implementation of Land Distribution and Compensation (amended and supplemented by Government Regulation No. 41 of 1964) which regulates as follows: "Owners of agricultural land residing outside sub-district of the land is located, within a period of 6 months shall transfer the rights of his land to other people who live in the sub-district where the land is located or he/she shall move to the sub-district where the land is located".

\section{Research Methods}

The method used in this study was the normative juridical. The main material was based on library studies in the form of library books and other supporting materials such as internet. ${ }^{7}$

\section{Discussion}

\subsection{Sales of Objects of Mortgage Right Through Auctions by KPKNL}

The term of paratee executie as described in the previous section, etymologically is derived from the word "paraat" means ready to be handled. Thus, the paratee executie is said to be a ready-to-do execution. According to the Law dictionary, the paratee executie has a direct implementation meaning without going through the process (Court or Judge).

The meaning of paratee executie is the authority to sell on its own power or if the debtor is defaulted, the creditor can execute the object of the guarantee, without having to ask fiat from the Chairman of the District Court

If the term paratee executie is implicitly absent in pledge and mortgage rules, but in UUHT (Law of Mortgage Right)the term paratee executie is implicitly expressed and implied. Particularly set out in the General Elucidation number 9 UUHT (Law of Mortgage Right) states: "One of the characteristics of a strong Mortgage Right is that it is easy and definite in the execution, if the debtor breaks the appointment. Although in general, the provisions on execution have been regulated in the applicable Civil Procedure Code, it is deemed necessary to include in particular the provisions on the execution of Mortgage Rights in this Law, which regulates the "paratee executie" institution as referred to in Article 224 of the updated Indonesian Regulation (Het

\footnotetext{
${ }^{6}$ Anis Mashdurohatun, Zaenal Arifin and Gunarto, "The Inconsistency of Parate Execution Object Warranty of Rights in Banking Credit Agreement in Indonesia", in International Journal of Applied Business and Economic Research Volume 15 Number 202017 p. 269

7 Soerjono, Soekanto,dan Sri, Mamudji, 2000, Penelitian Hukum Normatif, PT Raja Grafindo Persada,Jakarta, p. 14
} 
Herziene Inlands Reglement) and Article 258 Registration of Law Events for the outside Java and Madura Islands (Regular tot Regeling van Het Rechtswezen in de Gewesten Buiten Java en Madura) ..."

The regulation concerning the execution of Mortgage Rights shall be regulated in Article 20 paragraph (1) of UUHT, stating that if the debtor breaches the pledge, the holder of the first Deposit Rights to sell the object of Mortgage right as referred to in Article 6 UUHT (Law of Mortgage Right).

The execution of the object of the Mortgage Rights should not be based on Article 224 H.I.R. and 258 R.Bg., as mentioned by General Elucidation item 9 and Elucidation of Article 14 paragraph (2) and (3). Instead, the execution paratee was carried out without asking the fiat of the District Court Chief. The second explanation when connected with Article 6 UUHT, then constructed by juridical, then in execution the object of Mortgage Rights can be described as below:

First, the UUHT (Law of Mortgage Right) formers provide understanding of the execution of the object of the mortgage give double meaning. One meaning side is the implementation through public tender (Article $6 \mathrm{UUHT}$ ), but on the other hand, it must get fiat from the Chairman of the District Court (based on Article 224 HIR/258 R.Bg.). Double meaning creates a vague understanding (vage norman). It shows on the other hand, the inconsistent nature of UUHT Formers and the other side, its image on the value of legal certainty is never certain.

Second, if the execution of the object of Mortgage right under Article 6 UUHT is viewed from the nature of the law, the law is in the form of material law in which the nature of formal law or if the term given by Sudikno is a material law in which contained formal law. Entry into force of the creditor as the first holder of Mortgage Right to sell the object of Mortgage Right to must through a public tender, in case that the debtor breaches the agreement. The intent of a public auction means it is done without having to ask fiat from the Chairman of the District Court. If the paratee execution must pass and on the order of the Chairman of the District Court (Article 224 H.I.R.), it may be interpreted to deviate from Article 6 UUHT which is a substantive regulation. Therefore, when executing the object of Mortgage Rights, it must be through the fiat of the Chair of the District Court, it means that it violates the rule of Article 6 UUHT. Hence, the form of paratee execution object implementation of procedural rights has a substantive deviation rules. Distorted rules are certainly not to be used but deserve to be ignored or even unnecessarily used because they can be an obstacle to one of the purposes of the law namely usability principle (zwekmaszigkeit).

Third, the execution of the object of the Mortgage Right by the Formers of UUHT is not based on the norm contained in Article 6 UUHT which specifically regulates the execution paratee material. However, it uses an authentic interpretation, which refers to the formulation of the General Elucidation Section 9 and Elucidation of Article 14 paragraph (2) and (3) UUHT, which regulates the material of execution of the Certificate of Mortgage Rights. So that its implementation based on Article 224 H.I.R./258 R.Bg., results in a conflict of norms. Consequently, there is no amenity originally provided by the law to the first holder of the Mortgage Right if the debtor breaks the agreement.

In fact, to implement the provisions of Article $6 \mathrm{UUHT}$, the implementation guidance shall be regulated in Circular Letter of the State Receivable and Auction Affairs Agency Number: SE-21 / PN / 1998 on the Implementation Guidance Article 6 of the Mortality Rights Act specify that: "... The sale is not forcible, but is the act of execution of the agreement by the parties. Therefore there is no need to hesitate to serve the auction demand from the banking party on the Object of Mortgage based on Article 6 UUHT. " 


\subsection{Implementation of Land Registry Derived from Sale Through Auction}

The process of land registration pursuant to Article 41 paragraph (1) of Government Regulation Number 24 of 1997 concerning land registration explains that the transfer of rights through auction can only be registered if it is proven by the quotation of Auction Minutes made by the Auction Officer. Public sale may only be executed if there is evidence of Auction Minutes approved by the Auction Official. It should be noted, in every process of registration of land coming from the auction, if on the object of registration is attached to other rights such as the mortgage right, then the object of registration must be clean from the burden attached to the land or the right must be in Roya first. ${ }^{8}$

One of the requirements of land registrations, in auction, is that the land must be free from any other party's burden. According to Article 109 paragraph (2) Regulation of the Minister of Agrarian Affairs/Head of BPN No. 3 of 1997, that prior to the registration of the transfer of rights as referred to in paragraph (1), based on the statement from the Head of the Auction Office as referred to in Article 108 paragraph (2) shall be required to include a record of the existence of the seizure is deleted, as well as in paragraph (3) of the Article explains that based on quotations from the Auction Minutes and statements of creditors as referred to in Article 108 (3) records concerning the existence of the related Mortgage Rights are removed.

After the Land Office believes that there has been a write-off of the burden and the applicant has also attached or completed all the necessary requirements, the implementation of the transfer of rights may be processed, as for the requirements to register or transfer the rights due to the auction are as follows: ${ }^{9}$

- Application letter.

- Quotations of Auction Minutes.

- Original Certificate.

In case that the original Certificate is not given, there must be a statement from the Head of the Auction Office on the reasons for not submitting the Certificate in question.

- For non-execution auction, the lost certificates will be replaced. An announcement is made once for a month in the printed media (procedure of issuance of replacement Certificate due to missing is done separately).

- For auction execution, the certificate will be issued as a replacement of the lost certificate but with the new right number, the number of the previous certificate is deleted. The issue of the Certificate is announced in the mass media at the applicant's expense.

- The identity of the auction winner and/or his/her proxy (photo copy):

- Individual: ID card and Family card and legalized by authorized official.

- Legal entity: Agreement of Establishment and Legalization of Legal Entity, legalized by authorized official.

- Power of Attorney, if the petition is authorized.

- Proof of payment of purchase price.

- Proof of SSB BPHTB.

- Evidence of final PPH PPS settlement/auction result note.

- Certificate of Deposit Rights if burdened by Mortgage Right

\footnotetext{
${ }^{8}$ Salbiah,2004, Materi Pokok Pengetahuan Lelang; Pusat Pendidikan dan Pelatihan Perpajakan, Jakarta, p.2-3

${ }^{9}$ A.P, Parlindungan, 1990 Pendaftaran Tanah di Indonesia, Mandar Maju, Bandung, p. 113
} 
- The creditor's statement releases the Deposit Rights for an amount that exceeds the auction result.

- The minutes of the auction shall contain the information of Roya or the appointment of confiscation.

The documents are submitted to the Technical Officer or (Counter II), after the documents have been received, the Technical Officer shall examine all documents. If the document is found incomplete, it will be returned to the applicant for completion, but if the document is complete and the veracity is justified by the applicant. The Technical Officer will prepare a Document Receipt (STTD) and Payment Order Letter (SPS) and submit it to the applicant.

After the applicant obtains the original SPS (Payment Order Letter) and STTD (Document Receipt) from the Technical Officer, the applicant then makes a payment to the Treasurer of Acceptance Specials (BKP) in accordance with the fees listed in the SPS, and the Officer will make a receipt to the applicant, then the Officer will proceed a copy to the Technical Officer to be recorded in the application book.

The Technical Officer will forward the documents to the Sub Directorate of Registration and Transfer of Rights and Officers of the Land Agreement Officer (PPH and PPAT), PPH Sub-Head and PPAT (Land Agreement Officials) will examine and make a disposition (appointing the Executing Officer to process the document). After appointed several PPH, Implementing Officers and PPAT, then the PPH Implementing Officer and PPAT will borrow the Land Book to the Archive Officer and will correct or check all the completeness of the old Documents with the Land Book. Checking the PPAT Agreement (identity of the compassion etc) and will record the transfer of rights (write the buyer's name in old land book and delete the seller's name or the previous land owner). After that, the officials make a draft of the Certificate and Land Book on behalf of the new owner, and made a list of names, listing them on the old Certificate. All documents have been managed and corrected by PPH Officer and PPAT correctly, then the document will be sent directly to PPH Sub-division and PPAT to be corrected again. In case that the given document is considered incomplete or incorrect then the document will be returned to the Implementing Officer PPH and PPAT to be completed, but if the document is deemed appropriate and correct in its processing, the Head of PPH Sub-division and PPAT shall affix the transfer rights note in the Land Book and Certificate, and forward the document to the Head of Land Office.

Head of Land Office receiving documents from PPH Sub-Head and PPAT shall recorrect the documents provided, if the document is deemed incomplete or incorrect then the document shall be returned to the Implementing Officer of PPH and PPAT to be completed, but if the document is considered complete and then the Head of Office will affix the transfer of rights records in the Land Book and Certificate, and pass the documents to the PPH Implementing Officer and PPAT (Land Agreement Officials). After the submitted documents are complete with the approval of PPH Sub-Head and PPAT as well as from the Head of Land Office, PPH Officer and PPAT will provide the stamp of approval from the Land Office issuing the Certificate, and will return the Land Book to the Land Book Records Officer and submit documents Warkah to the Warkah Archives Officer, and will subsequently submit the certified Certificate to the BKP Officer.

Documents provided by PPH Officer and PPAT to the BKP Officer will be recorded in the list and forward the document to the Officer of Certificate Officer (counter IV). Officer Counter IV will provide the Certificate authorized to the applicant, and will record the list in the Land Book and Certificate, records the date of receipt of the Certificate by 
the applicant, by mentioning the number of the list, and archiving the document in the archive.

\section{Conclusion}

Selling the Mortgage Rights Objects by auction based on the execution paratee Article 6 UUHT is as a means to accelerate the settlement of accounts receivable when the debtor is defaulted.

The Auction of Execution of Object of Mortality Right carried out by KPKNL is Paratee Execution under Article 6 UUHT. Implementation of the Auction shall be conducted by the Auction Officer and may be assisted by the Auction Guide. Offering the price in an open or oral and closed or written or inclusive and exclusive manner, preceded by an announcement, and in the auction shall be determined the existence of a deposit, auction fee and a limit price.

The process of registration of land arising from the sale of auction can only be proven by the Auction Minutes made by the Auction Official, if the physical data and juridical data of the land concerned has not been registered then the land examination shall be required and in SKPT. It is mentioned that the land has not been registered, the Land Office shall issue a substitute certificate if the registration of the transfer of rights due to the auction of execution whose certificate cannot be submitted.

\section{References}

[1] Anis Mashdurohatun, Zaenal Arifin and Gunarto, "The Inconsistency of Parate Execution Object Warranty of Rights in Banking Credit Agreement in Indonesia", in International Journal of Applied Business and Economic Research Volume 15 Number 202017

[2] Boedi Harsono, 1999, Hukum Agraria Indonesia, Sejarah Pembentukan Undangundang Pokok Agraria, isi dan pelaksanaannya, Revision Edition, Djambatan.

[3] L.J. Van Apeldorn Mr, 2001, Pengantar IImu Hukum, Pradnya Paramita, Jakarta

[4] Harun Al-Rashid, 1997, Sekilas Jual Beli Tanah, Ghalia Indonesia, Jakarta

[5] Salbiah,2004, Materi Pokok Pengetahuan Lelang; Pusat Pendidikan dan Pelatihan Perpajakan, Jakarta

[6] A.P, Parlindungan, 1990 Pendaftaran Tanah di Indonesia, Mandar Maju, Bandung

[7] Soerjono, Soekanto,dan Sri, Mamudji, 2000, Penelitian Hukum Normatif, PT Raja Grafindo Persada,Jakarta 